\title{
KONSEP REKABENTUK KASUT BOLA SEPAK MASA HADAPAN DENGAN PEN- DEKATAN BIOMEKANIK
}

\author{
MOHD FIRDAUS MAHAMAD ALI* \\ AHMAD RASDAN ISMAIL** \\ MHD HAFIZ KARAMI BIN MHD ZAIN***
}

\begin{abstract}
Abstrak
Pada masa kini, perkembangan sains dan teknologi telah mendorong para penyelidik memajukan pelbagai bidang di seluruh dunia termasuklah dalam bidang sukan. Di dalam bidang sukan, para penyelidik telah banyak membuat kajian tentang prestasi dan pekembangan atlet untuk setiap jenis sukan dengan menggunakan analisis biomekanik. Seramai enam orang subjek menggunakan kaki dominan kanan dan bebas daripada sebarang kecederaan dari pelbagai kategori telah dipilih sebagai subjek dalam kajian ini. Pengambilan data dilakukan dengan mengambil video apabila tendangan dilakukan oleh subjek dengan menggunakan beberapa buah kamera berkelajuan tinggi. Kajian ini dijalankan dengan menggunakan empat keadaan dan jenis kasut yang berbeza. Soalan soal selidik telah dibangunkan yang mana ia menumpukan kepada kualiti, jenis ikatan dan keselesaan. Soal selidik ini akan dianalisis menggunakan perisian SPSS 15.0. Di samping itu, analisis ini akan mengkaji data yang diperolehi dan mencadangkan kasut yang sesuai untuk dibangunkan pada masa akan datang.
\end{abstract}

Kata Kunci: Biomekanik, Sukan, Antropometri, Kasut

\footnotetext{
* Pensyarah di Fakulti Teknologi Kreatif dan Warisan, Universiti Malaysia Kelantan (UMK).

** PhD, Profesor Madya dan Ketua Unit Pengurusan Persekitaran, Keselamatan dan Kesihatan Pekerjaan (UMK).

*** Pensyarah di Fakulti Teknologi Kreatif dan Warisan, Universiti Malaysia Kelantan (UMK)
} 


\begin{abstract}
At present, the development of science and technology has prompted researchers to develop various areas around the world, including in the field of sports. In the field of sports, many researchers have made a study of the performance and the expanding athletes for each sport by using biomechanical analysis. A total of six subjects using the dominant right foot and free of any injuries from the various categories were chosen as subjects in the study. Data acquisition is done by taking video when the kick is made by the subjects using a number of high-speed camera. This study was conducted using four conditions and different types of shoes. The questionnaire was developed which focuses on the quality, type and comfort. This questionnaire will be analyzed using SPSS 15.0. In addition, this analysis will examine the data and recommend appropriate footwear to be developed in the future.
\end{abstract}

Keywords: Biomechanics, Sport, Anthropometric, Shoe

\footnotetext{
* Pensyarah di Fakulti Teknologi Kreatif dan Warisan, Universiti Malaysia Kelantan (UMK).

** PhD, Profesor Madya dan Ketua Unit Pengurusan Persekitaran, Keselamatan dan Kesihatan Pekerjaan (UMK).

*** Pensyarah di Fakulti Teknologi Kreatif dan Warisan, Universiti Malaysia Kelantan (UMK) 


\subsection{Introduction}

Analisis biomekanik merupakan kajian ke atas daya dan kesan daya tersebut pada tubuh badan manusia. Apabila daya dikenakan kepada tubuh badan manusia, maka, bidang biomekanik ini boleh digunakan untuk menganalisa dan mengenalpasti sebab dan kesannya. Secara terperincinya maksud biomekanik boleh dipecahkan kepada dua iaitu bio dan mekanik. Perkataan Bio membawa maksud kehidupan atau sistem biologi. Bagi perkataan Mekanik pula ia membawa maksud kajian atau analisa terhadap daya dan kesannya. Biomekanik juga boleh didefinisikan sebagai kajian atau aplikasi bagi prinsip mekanik dalam kehidupan yang membawa kaedah kejuruteraan (Ginnis 2005).

Di dalam sukan, biomekanik lebih menumpukan secara meluas terhadap prestasi persembahan. Bagaimanapun, tumpuan turut diberikan terhadap faktor-faktor yang boleh mempengaruhi prestasi dan persembahan atlet, sebagai contoh, pakaian, kasut, permukaan serta peralatan. Asas kepada biomekanik dalam bidang sukan adalah berkaitan dengan mekanik itu sendiri serta anatomi dalam sistem musculoskeletal (Bartlett 2007). Biomekanik melibatkan dua aspek yang berbeza iaitu kinetik dan kinematik. Kinematik adalah suatu kajian berkaitan dengan geometri, bentuk atau bentuk pergerakan dengan mengambilkira faktor masa (Susan 2003).

Untuk peralatan pemain seperti kasut ia memainkan peranan yang amat penting. Pada dasarnya, kestabilan sistem kasut memungkinkan kasut direka mengikut kesesuaian kaki dan mampu mencegah risiko kecederaan otot tulang di samping memberi keselesaan kepada pemakai. Bagi seseorang pemain bola sepak, penginderaan atau 'sensing' pada kasut adalah amat penting (Hennig \& Sterzing, 2010) 'Soccer stress fracture', luka yang berlebihan daripada 'locomotors apparatus', serta pergelangan kaki dan lutut yang terseliuh pada asalnya sering terjadi baik kepada pemain amatur mahupun profesional. Untuk menganalisis interaksi pengaruh permukaan kasut kaki, kita harus mempertimbangkan pelbagai aspek, seperti persekitaran dan peralatan. Pentingnya kasut khusus atau 'insole design' adalah perlu bagi untuk mencegah sebarang kecederaan. 


\subsection{Latar belakang kajian}

\subsection{Analisis 'Studs'}

Salah satu faktor yang paling penting berkaitan dengan prestasi dan kecederaan adalah antara kesan antara permukaan kasut dan permukaan padang. Cengkaman yang baik penting bagi melakukan pecutan, perubahan arah pergerakan dan menendang. 'Studs' pada kasut bola adalah faktor penting dalam memberikan cengkaman antara kasut dan gelanggang (García et al. 1999).

Pada setiap kasut bola sepak, 'studs' bergantung pada kedudukan dan ianya mempunyai fungsi yang berbeza selain menjadi tempat untuk mengunci yang mampu mengelakkan dari berlaku kecederaan berdasarkan faktor morfologi. Kebanyakan pengeluar telah mereka bentuk dan menyelaras stud mereka dalam orientasi yang menghasilkan daya tarikan di setiap arah. Cengkaman berlebihan menyebabkan penempelan pada tanah di tanah, sementara cengkaman yang baik mampu mengelakkan tergelincir (García et al. 1999).

Kajian lalu dilakukan untuk mempelajari karakteristik dan membandingkan gaya mendatar pada setiap stud bola sepak ketika kita melakukan gerakan berbeza dalam sepak bola. Kajian ini menetapkan nombor stud di setiap kasut. Fungsi 'studs' diaplikasikan pada saat ini dengan meningkatkan pergerakan ketika memecut dan mengubah arah. Satu ujikaji untuk mengkaji fungsi 'studs' telah dibangunkan seperti Rajah 1.

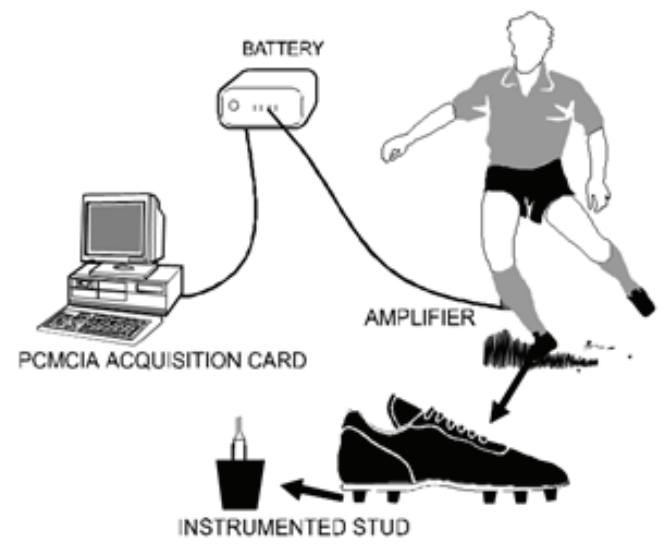

Rajah 1: Cara Mengkaji Tekanan Pada 'Studs' Sumber: (García et al. 1999) 
Rajah 2 menunjukkan bahagian hadapan luar 'studs' mempunyai kekuatan yang lebih tinggi. Kekuatan 'studs' di bahagian belakang pula didapati sangat rendah di mana sebahagian besar gerakan yang dalam gerakan bersilang-silang. Keputusan ini menunjukkan adanya perbezaan dalam kedudukan 'studs' yang ditentukan oleh arah beban. Ini menunjukkan adanya bidang yang berbeza yang memerlukan parameter-parameter reka bentuk pelbagai untuk 'studs' .

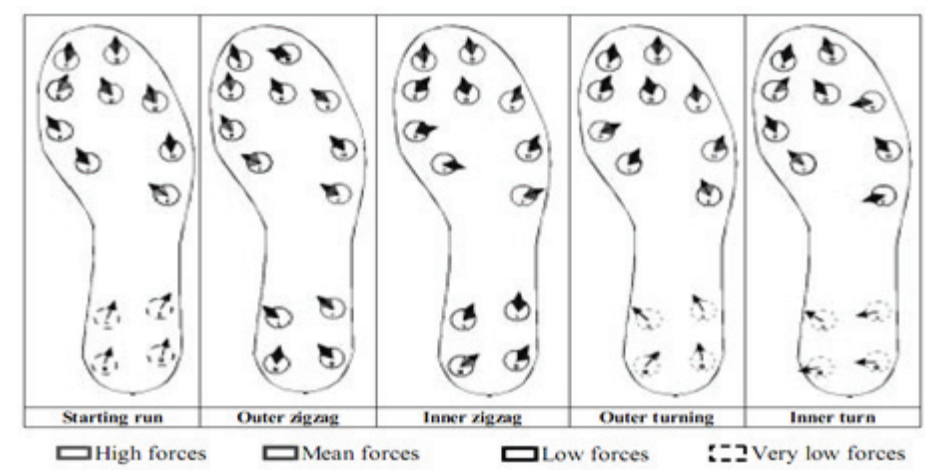

Rajah 2 : Bahagian hadapan luar 'Studs' mempunyai kekuatan yang lebih tinggi

\subsection{Antropometri Segmen Kaki}

Menurut Nurmianto (1996) antropometri adalah satu kumpulan data numerik yang berhubungan dengan sifat fizikal bagi tubuh manusia, ukuran, bentuk dan kekuatan bagi meningkatkan prestasi ketika melakukan sesuatu kerja atau aktiviti. Hal-hal yang berkaitan dengan dimensi tubuh manusia ini dipelajari dalam antropometri. Antropometri berasal dari perkataan "antrophos" dan "metros". "Antrophos" membawa maksud manusia manakala, "metros" adalah ukuran. Antropometri bermaksud ukuran dari tubuh badan manusia (Potter \& Perry 2006). 
Antropometri boleh dipecahkan kepada dua bahagian iaitu antropometri statik yang bermaksud pengukuran yang dilakukan ketika tubuh badan manusia dalam keadaan tidak bergerak. Dimensi yang diukur pada posisi ini adalah berat badan, tinggi badan ketika berada di dalam posisi berdiri ataupun duduk, ukuran kepala, dan lain-lain. Bahagian yang kedua adalah antropometri dinamik yang bermaksud pengukuran dimensi tubuh yang diukur dalam pelbagai posisi ketika tubuh sedang bergerak.

Terdapat beberapa faktor yang mempengaruhi ukuran antropometri seseorang manusia antaranya adalah umur, jantina, bangsa dan jenis pekerjaan. Data antropometri merupakan data ukuran dimensi tubuh manusia. Data antropometri sangat berguna dalam perancangan suatu produk dengan tujuan mencari keserasian produk dengan manusia yang menggunakannya. Dimensi tubuh manusia yang perlu diambilkira adalah berat dan pusat masa dari suatu segmen tubuh, bentuk tubuh, jarak untuk gerakan dari tangan dan kaki, dan lain-lain.

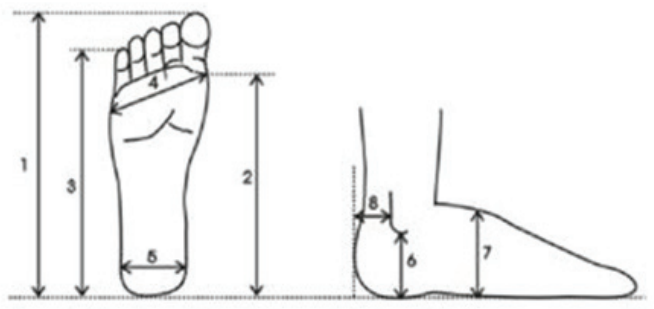

Rajah 3 : Ukuran antropometri

2.3

\section{Berat Segmen Kaki}

Persamaan bagi mendapatkan jisim kaki yang menendang ini diambil daripada buku Research Method in Biomechanic (Gorldon et al. 2004). Pada asasnya, jisim untuk segmen pada struktur bawah badan terbahagi kepada tiga iaitu jisim kaki, jisim betis dan juga jisim peha. Persamaan (1), (2), (3) dan (4) digunakan untuk mengira jisim bagi segmen kaki yang melakukan tendangan.

mkaki $=0.0083$ mtotal $+254.5($ Itapak kaki hbuku lali $\omega$ buku lali $)-0.065$

mbetis $=0.0226$ mtotal +31.33 (lbetis c2betis $)+0.016$

mpaha $=0.1032 \mathrm{mtotal}+12.76($ Ipeha c2peha $)+1.032$

mkeseluruhan $=$ mkaki + mbetis + mpaha

Di mana mkeseluruhan = jisim keseluruhan badan; $\mathrm{h}$ buku lali = tinggi buku lali; $\omega$ buku lali = lebar buku Iali; cpeha = diameter peha; cbetis = diameter betis; $I$ = panjang setiap segmen . 


\subsection{Kesan Tendangan Menggunakan Kasut Berlainan}

Tendangan yang kencang atau pantas boleh menyebabkan perbezaan untuk menjaringkan gol dalam sebuah permainan dan dengan demikian kelajuan menendang harus dilihat sebagai faktor penentu keberhasilan gol dalam permainan bola sepak. Sterzing et al. 2007 menyatakan model kasut bola sepak yang berbeza dapat menghasilkan halaju bola yang berbeza sewaktu menendang. Kasut bola bertindak sebagai antara muka antara kaki dan bola. Ini perlu untuk melindungi kaki pemain tetapi harus juga membolehkan bola merasai kesan yang optimal, sehingga menyokong kemampuan teknikal pemain.

Kadar pemindahan getaran luaran rangsangan ke kaki melalui permukaan kasut bola sepak berkemungkinan akan bergantung pada jenis dan ketebalan bahan atas kasut. Kasut bola sepak mengurangkan getaran kepekaan terhadap rangsangan luaran. Rajah 4 pula menunjukkan struktur dan kedudukan tulang pada bahagian tapak kaki. Kepekaan getaran diukur di empat lokasi anatomi tapak kaki seperti:

- MM-I medial metatarsal head I

- DM-I dorsal metatarsal head I

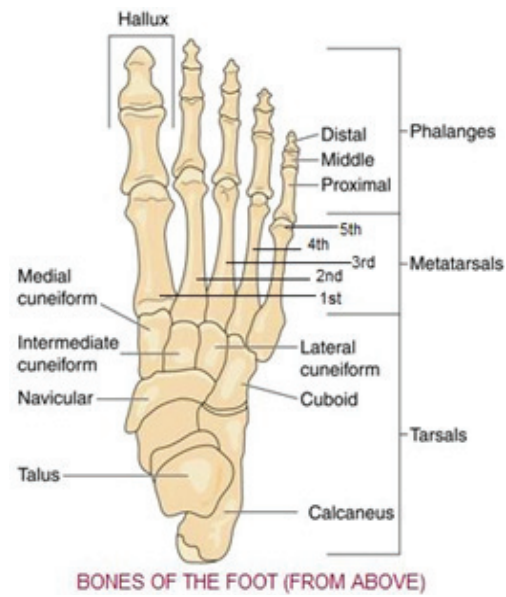

Rajah 4 : Struktur dan kedudukan tulang pada bahagian tapak kaki 


\subsection{Kaedah Kajian}

Seramai enam orang pemain bola sepak yang menggunakan kaki dominan kanan dan terdiri daripada pelbagai kategori telah dipilih sebagai subjek dalam kajian ini. Pemain-pemain yang telah dipilih merupakan pemain bola sepak yang bebas dari sebarang kecederaan dan memenuhi saiz kaki purata lelaki Asia dan bermain di posisi yang merangkumi permainan bola sepak iaitu daripada posisi pertahanan, tengah dan penyerang. Ujian saringan kecederaan akan dilakukan ke atas subjek sebelum subjek melakukan ujikaji. Data anthropometri dan demografik subjek telah direkodkan. Kajian ini dijalankan dengan menggunakan empat keadaan kasut yang berbeza. Semua kasut mempunyai ketebalan yang berbeza dan lebar. Pengambilan data dilakukan dengan mengambil video apabila tendangan dilakukan oleh subjek dengan menggunakan beberapa buah kamera berkelajuan tinggi yang mana kamera tersebut akan diletakkan di sekeliling tempat ujikaji. Pengambilan gambar dibuat pada subjek dari bahagian bawah badan iaitu dari paras pinggang ke bahagian lutut dan ke buku lali. Beberapa parameter telah dikenalpasti sebagai soalan soal selidik yang mana ia menumpukan kepada kualiti, jenis ikatan, ketepatan tendangan dan keselesaan. Soal selidik ini akan dianalisis menggunakan perisian SPSS 15.0. Rajah 5 menunjukkan 4 jenis kasut dan satu tendangan yang tidak menggunakan kasut dalam kajian ini.
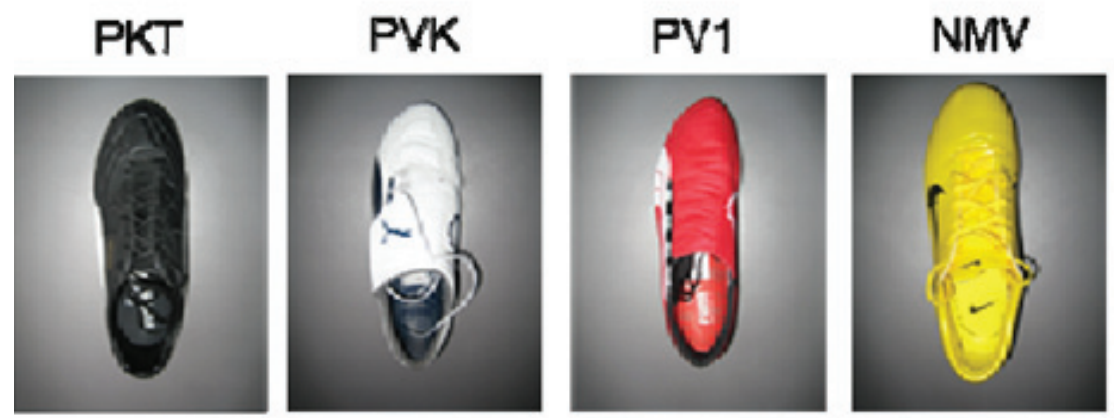

Rajah 5: Empat Jenis Kasut dan Satu Kaki Biasa Yang Digunakan Dalam Ujikaji

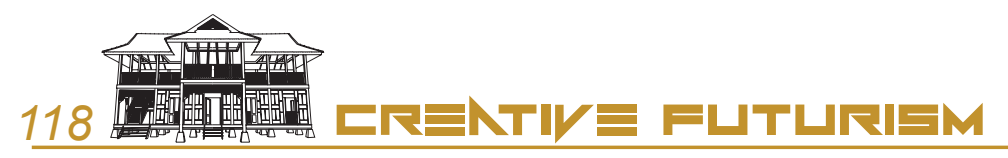




\subsection{Keputusan dan Perbincangan}

\subsection{Bahagian Luar Kasut}

Berdasarkan dari data soal selidik dan data kajian yang diperolehi, kebanyakan subjek lebih cenderung memilih kasut keluaran Puma yang mana dari segi kualiti bahan yang digunakan lebih memberi keselesaan pada subjek sewaktu memakai, berlari dan menendang. Kasut keluaran Puma ini menggunakan bahan di bahagian luar yang berunsur 'PEBAX' iaitu satu bahan dari unsur elastomer termoplastik. 'PEBAX' ini merupakan suatu bahan yang mempunyai beberapa unsur atau campuran dua segmen yang berlainan iaitu dari Poliamida dan juga Polieter. Kelebihan utama bahan 'PEBAX' ini adalah kerana bahan ini mempunyai ketumpatan yang rendah berbanding elastomer termoplastik yang lain.

Bahan ini menjadi pilihan bagi kebanyakan pengeluar barangan sukan terutamanya untuk penghasilan kasut sukan atau kasut bola yang berkualiti tinggi kerana bahan ini mampu menghasilkan kekuatan maksimum ketika sokongan diperlukan sewaktu beraksi dan kelebihan bahan untuk menjadi lebih fleksible ketika menukar pergerakan secara ekstrim sekaligus dapat mengurangkan risiko kecederaan pada pergelangan kaki. Rajah 6 menunjukkan graf modulus kelenturan melawan kekerasan.

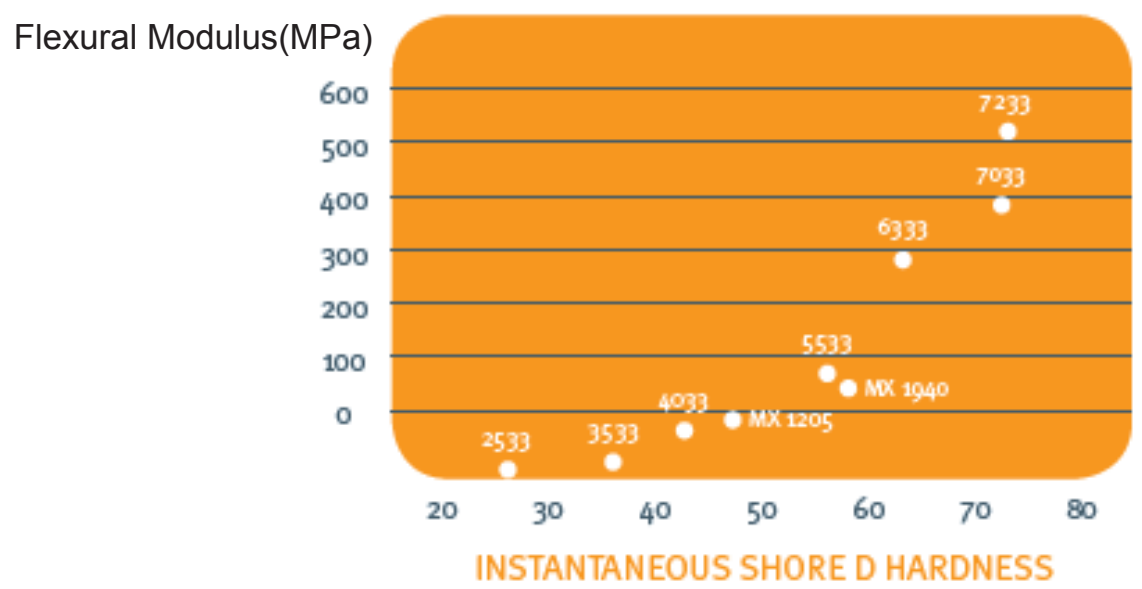

Rajah 6: Graf Modulus Lentur melawan Kekerasan 
Kasut yang baik dan selesa adalah kasut yang tidak menambah beban yang keterlaluan kepada pemain bola sepak ketika bergerak. Dari data soal selidik, antara cadangan yang dikemukakan adalah menghasilkan kasut yang ringan tetapi berprestasi tinggi seperti menggunakan bahan yang digunakan dalam penghasilan kasut Puma tersebut. 'PEBAX' ini merupakan bahan yang mempunyai ciri-ciri itu kerana bahan ini selain dari fleksibilitinya, bahan ini mampu menghasilkan kasut yang ringan kerana kecenderungan bahan yang mempunyai ketumpatan yang rendah. Kasut yang ringan bermakna langkahan dan hayunan seorang pemain lebih laju sekaligus meningkatkan kelajuan sepakan dan ketepatan hantaran. Bahan ini juga merupakan unsur yang tahan lasak kerana ia mampu menahan bebanan berulang dan mengelakkan berlaku kecacatan pada permukaannya sekaligus mengelak kasut dari cepat rosak. Kelebihan memilih bahan ini ianya mampu mengurangkan beban sesuatu kasut sehingga hampir 20\% dari berat asal. Jadual 1 menunjukkan jadual perbezaan ketumpatan.

Jadual 1: Jadual Perbezaan Ketumpatan

\begin{tabular}{lcll}
\hline $\begin{array}{l}\text { Polymer } \\
\text { Type }\end{array}$ & $\begin{array}{l}\text { Density } \\
\text { PEBAX }\left(\mathrm{kg} / \mathrm{m}^{3}\right)\end{array}$ & $\begin{array}{l}\text { Density Poli } \\
\text { Ester } \\
\text { Elastomer }\left(\mathrm{kg} / \mathrm{m}^{3}\right)\end{array}$ & $\begin{array}{l}\text { Density } \\
\mathrm{TPU}\left(\mathrm{kg} / \mathrm{m}^{3}\right)\end{array}$ \\
\hline $\begin{array}{l}\text { Soft } \\
\text { Grade }\end{array}$ & 1.01 & $1.18-1.20$ & $1.21-1.25$ \\
$\begin{array}{l}\text { Rigid } \\
\text { Grade }\end{array}$ & 1.02 & $1.22-1.26$ & $1.25-1.26$ \\
\hline
\end{tabular}

Bahan yang mempunyai kadar kehilangan tenaga yang rendah amat penting dalam satu penghasilan suatu kasut bola sepak. Pemindahan tenaga dari kasut ke bola ketika menendang boleh ditakrifkan sebagai satu pemindahan daya dari kaki ke bola melalui kasut yang mana bahan di luar kasut memainkan peranan penting. Daripada Rajah 7, didapati kadar kehilangan kuasa yang dipindah adalah rendah yang bermaksud kuasa yang dipindah dari kaki ke bola adalah hampir dipindahkan sepenuhnya. 'PEBAX' merupakan suatu bahan dari kategori elastomer termoplastik yang mempunyai cirri-ciri ini. Hal ini sekaligus membantu dalam pemilihan bahan ini sebagai bahan yang patut digunakan sebagai permukaan luar kasut bola.

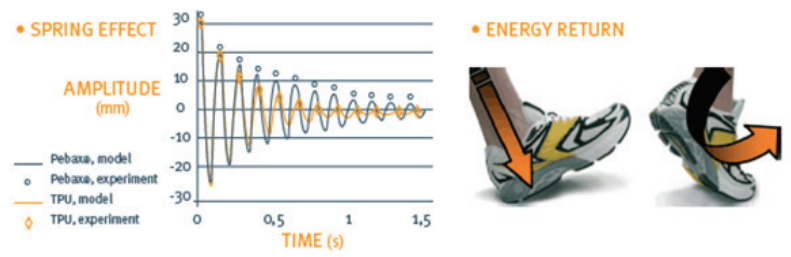

Rajah 7: Graf Kesan Pantulan terhadap Masa 


\subsection{Bahagian Tumit Kasut dan Tapak Kasut}

Dalam kebanyakan penghasilan kasut, dua bentuk studs menjadi pilihan utama iaitu samada dari segi bentuk studs yang memanjang atau yang membulat. daya yang maksimum dan kelajuan maksimum berlaku bila kasut bola tersebut mempunyai studs yang berbentuk bulat. Hal ini mungkin disebabkan kasut seperti ini mempunyai cengkaman yang lebih dan membolehkan subjek membuat hayunan yang berkesan dan berkelajuan tinggi. Bahan yang selalunya digunakan dalam penghasilan bahagian bawah kasut bola adalah bahan yang ringan tetapi mempunyai tahap kekuatan tarikan yang tinggi. Hal ini kerana jika kasut dihasilkan dengan menggunakan bahan yang kuat tetapi berat, pemain akan merasa tidak selesa ketika berlari. Bahan yang selalunya menjadi pilihan kebanyakan pemain bola sepak adalah bahan yang dinamakan Termoplastik Poli Urethane.

Bahan ini merupakan bahan yang berkualiti tinggi dan mampu memenuhi cirri-ciri yang diperlukan dalam penghasilan sebuah kasut yang baik. Bahan ini mempunyai kekuatan yang tinggi dan ringan. Penting menggunakan bahan seperti ini adalah dapat mengelakkan subjek dari mengalami kecederaan akibat terjahan yang keras dan juga ketika keadaan padang yang tidak stabil. Bahan ini juga merupakan bahan yang mudah dibentuk dan juga amat fleksibel sekaligus penghasilan kasut yang baik dapat dihasilkan dengan mudah.

\begin{tabular}{|c|c|c|c|}
\hline \multicolumn{4}{|l|}{ Mechanical } \\
\hline Bulk Modulus & $=0.7306$ & -0.7672 & $10 \frown 6 \mathrm{psi}$ \\
\hline Compressive Modulus & $=0.4873$ & -0.512 & $10 \frown 6$ psi \\
\hline Compressive Strength & $=11.89$ & -13.1 & ksi \\
\hline Elongation & 18.6 & -21.5 & $\%$ \\
\hline Elastic Limit & $=9.909$ & -10.92 & ksi \\
\hline Endurance Limit & -4.567 & $-\quad 5.937$ & ksi \\
\hline Flexural Modulus & 0.4859 & -0.5105 & $10 \wedge 6$ psi \\
\hline Fracture Toughness & -4.434 & $-\quad 5.877$ & ksi.in $1 / 2$ \\
\hline Hardness - Vickers & -20.5 & -22.6 & HV \\
\hline Hardness - Rockwell M & $=84$ & -92 & \\
\hline Hardness - Rockwell R & $=115$ & -125 & \\
\hline Izod Toughness & 23.79 & $-\quad 26.17$ & ft.lbf/in $\sim 2$ \\
\hline Loss Coefficient & $=0.01654$ & -0.01712 & \\
\hline Modulus of Rupture & 8.572 & -9.456 & ksi \\
\hline Poisson's Ratio & -0.3811 & -0.3965 & \\
\hline Shape Factor & 5.2 & & \\
\hline Shear Modulus & -0.1754 & 0.1843 & 10^6 psi \\
\hline Tensile Strength & 12.39 & 13.65 & ksi \\
\hline Young's Modulus & 0.4873 & 0.512 & $10 \frown 6 \mathrm{psi}$ \\
\hline
\end{tabular}

Rajah 8: Jadual Sifat Mekanik Termoplastik Poli Urethane 


\begin{tabular}{|c|c|c|c|c|c|c|}
\hline & $\begin{array}{c}\text { General } \\
\text { TPU }\end{array}$ & $\mathbf{T P R}$ & $\begin{array}{l}\text { Polyoster } \\
\text { Elastomer }\end{array}$ & $\begin{array}{c}\text { Flexible } \\
\text { Vinyl }\end{array}$ & $\begin{array}{l}\text { Neoprene } \\
\text { Chloroprene }\end{array}$ & Nylon \\
\hline Tensile Strength $(\mathrm{kg} / \mathrm{cm})$ & $300-600$ & $50-250$ & $300-600$ & $70-250$ & $70-250$ & $500-900$ \\
\hline Hardness (Shore) & $55 A-75 D$ & S5A- 50D & $90 A-70 D$ & $40-90 A$ & $20-90 A$ & 80R -115R \\
\hline Specific Gravity $(g / \mathrm{cm})$ & $1.10-1.25$ & $0.83-1.2$ & $1.17-1.22$ & $1.2 \cdot 1.4$ & 1.23 & $1.10-1.15$ \\
\hline Elongation (\%) & $300-700$ & $150-1000$ & $500-800$ & $200-400$ & $100-700$ & $40-300$ \\
\hline Abrasion Resistance & (0) & $\mathbf{x}$ & 0.0 & O & $\circ$ & 0.0 \\
\hline Compression Set & O & O & $\triangle$ & $\Delta$ & $\circ$ & - \\
\hline Tear Strength (kg/cn) & $\mathbf{0}$ & $\mathbf{x}$ & (1) & $\circ$ & $\odot$ & 웅 \\
\hline $\begin{array}{l}\text { Low Temperature } \\
\text { Flexibility }\end{array}$ & (1) & O & ○ & $\Delta$ & O & $\cdot$ \\
\hline \multicolumn{7}{|l|}{ Solvent Resistance } \\
\hline Aliphatic Hydrocarbon & (6) & $\mathbf{x}-0$ & (1) & O & O & 0 \\
\hline Aromatic Hydrocarbon & 0 & $\triangle$ & ( & $\mathbf{x}$ & $\mathbf{x}$ & - \\
\hline
\end{tabular}

( ) : Excellent $\bigcirc$ : Good $\triangle$ : Fair $\times$ : Poor

Rajah 9: Perbezaan Sifat Mekanik Bahan Yang Berlainan

\subsection{Bahagian Jenis Ikatan}

Faktor ikatan mungkin memainkan peranan dari segi gaya dan juga kelajuan tendangan. Reka bentuk kasut yang mempunyai ikatan di bahagian tepi dilihat ada mempengaruhi kelajuan tendangan. Dalam kajian ini, kebanyakan halaju berkelajuan tinggi dapat dihasilkan oleh kasut yang mempunyai ikatan di bahagian tepi. Selain itu, dari segi gaya dan keselesaan, subjek lebih cenderung memilih kasut yang mempunyai ikatan seperti ini tetapi harus diingat bahawa kasut yang ada pelindung tidak mempengaruhi langsung terhadap halaju sepakan mahupun pada keselesaan subjek. Pelindung ikatan ini boleh diabaikan sama sekali.

\subsection{Rekabentuk Kasut}

Satu cadangan reka bentuk kasut bola sepak yang mempunyai ciri-ciri biomekanik yang diperlukan bagi meningkatkan prestasi seseorang atlit bola sepak telah dapat dihasilkan dalam kajian ini seperti yang ditunjukkan dalam Rajah 10 dan 11 . 


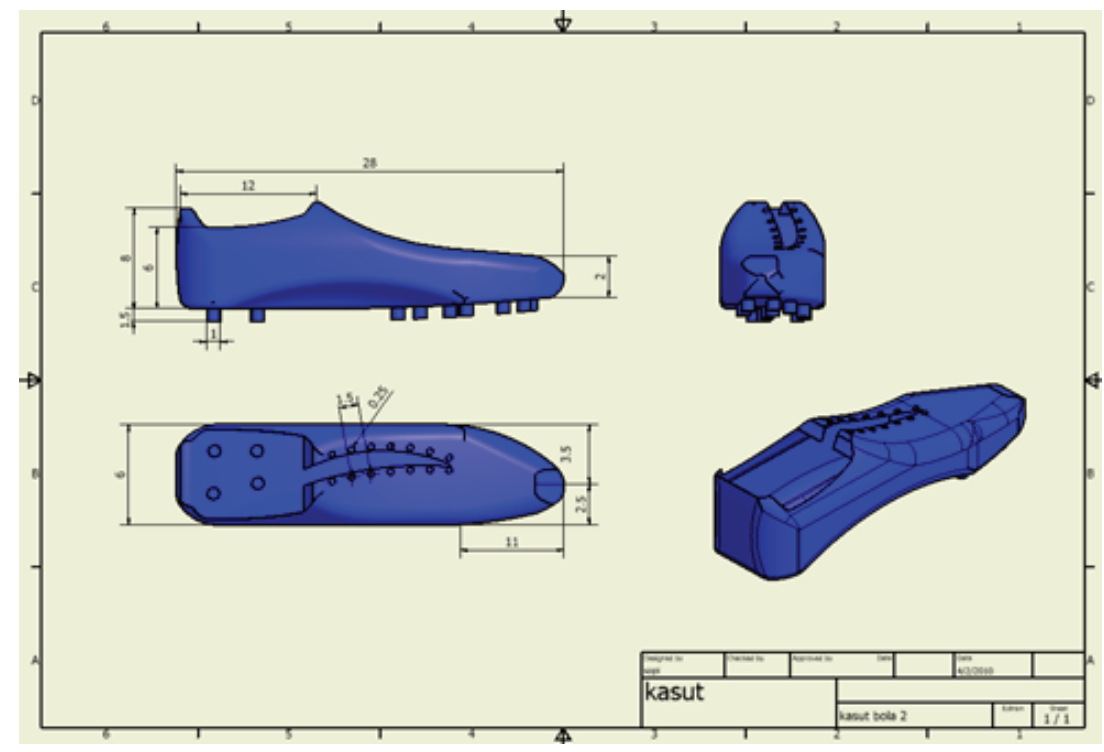

Rajah 10: Struktur reka bentuk kasut

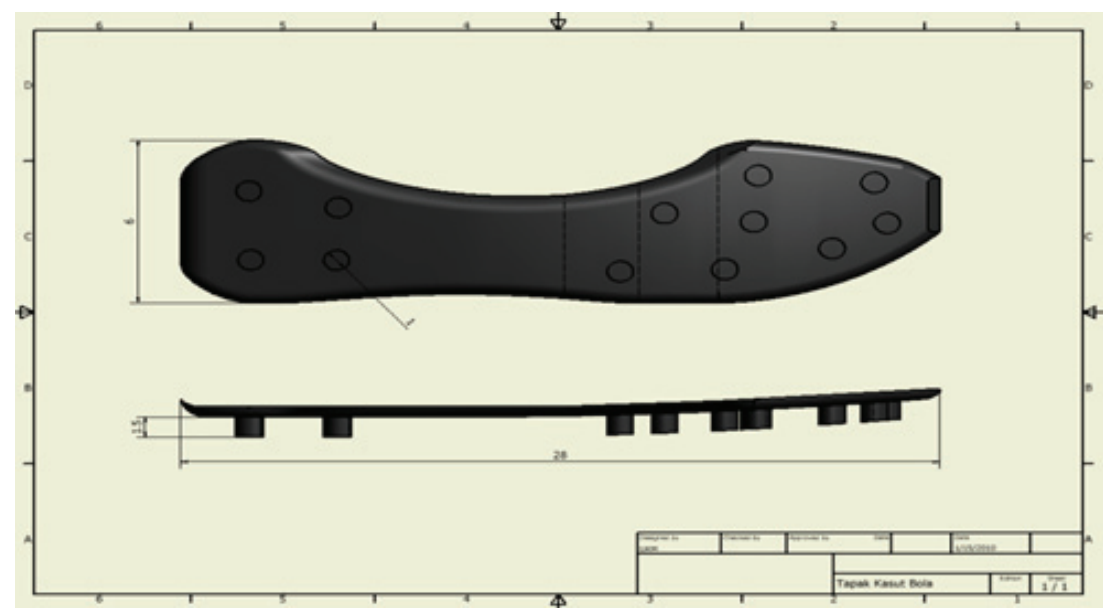

Rajah 11: Struktur reka bentuk tapak kasut 


\subsection{Kesimpulan}

Satu cadangan reka bentuk bagi menghasilkan sepasang kasut bola sepak yang mempunyai ciri-ciri biomekanik dan sesuai untuk dibangunkan pada masa akan datang telah dapat dihasilkan. Reka bentuk ini dapat dibuat dengan memfokuskan kepada beberapa perkara dan jenis bahan yang telah ditentukan. Dengan kewujudan kasut ini, ia dapat memberikan keselesaan dan mengurangkan kecederaan kepada pemain bola sepak.

\section{Rujukan}

Bartlett, R. 2007. Introduction to Sports Biomechanics: Analysing Human Movement Patterns. Routledge; 2 editions

García, A.C., Martínez, A., Solaz, J.S., Montero, J., Durá, J.V., Ramiro., J.F. 1999. Development Of A Method For Measuring Horizontal Forces Soccer Boots Studs During

Skill Performance. Fourth Symposium on Footwear Biomechanics.

Ginnis P. M., 2005. Biomechanics of Sport and Exercise. 2nd Edition. ISBN-13: 9780736051019

González, J.C., Martínez, A., Montero, J., Alemany, s., Gámez, J. 2003. Analysis Of The Horizontal Forces In Soccer Boot Studs For Specific Movements. Sixth Symposium of the ISB Technical Group on Footwear Biomechanics.

Gorldon R., Graham C., Joseph H., Gary K. and Sandy W., 2004. Research Methods in Biomechanics.

Hennig, E. \& Sterzing, T. 2010 The influence of soccer shoe design on playing performance a series of biomechanical studies - Footwear Science 2(1): 3-11

Nurmianto, E. 1996. Ergonomi, Konsep Dasar dan Aplikasinya. PT. Guna Widya:

Surabaya.

Potter \& Perry. 2006. Buku Ajar Fisiologi Kedokteran Edisi 11. Jakarta: Penerbit Buku Kedokteran EGC

Susan J. H., 2003. Basic Biomechanics, 4th edition. the University of Michigan. Mc Graw Hill

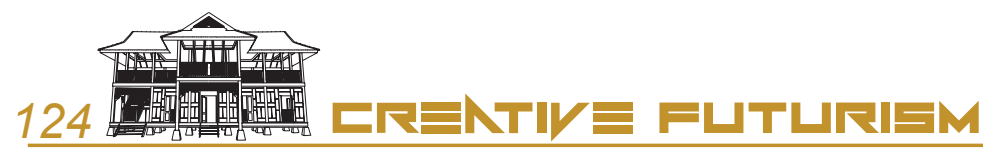

